\title{
ANALISIS FAKTOR RESIKO KEJADIAN STUNTING PADA ANAK USIA 12-59 BULAN DI PROVINSI NUSA TENGGARA BARAT
}

\author{
Novia Dewi Anggraini \\ Program Studi S1 Ilmu Kesehatan Masyarakat \\ Fakultas Kesehatan Masyarakat, Universitas Airlangga \\ Email: noviangeblog@gmail.com
}

\begin{abstract}
Stunting among children under five can giving bad impact for chidren because it make less optimum of brain development. In 2017, there was 37,2\% children under five years West Nusa Tenggara Province experience stunting. This study aimed to assess risk factor of stunting among children under five years in West Nusa Tenggara Province.This study was secondary data analysis from Indonesian Family Life Survey wave 5 (IFLS-5) in 2014-2015. Samples of this research were children age 12-59 months in West Nusa Tenggara Province. The number of the samples was 456 children. The relationship between variables were analyzed by chi-square test and the relative risk were analyzed by logistic regression. Result show that risk factor of stunting among children age 12-59 months in West Nusa Tenggara Province were weight of birth less than 2500 gram $(p=0,001 ; O R=3,303 ; 95 \% C I=1,6-6,816)$, anemia of children $(p=0,001 ; O R=2,199 ; 95 \% C I$ $=1,469-3,291)$, age of mother at birth less than 18 years old $(p=0,001 ; O R=6,867 ; 95 \% C I=$ $1,481-31,834)$, age of mother at birth more or same with 35 years old $(p=0,001 ; O R=0,515 ; 95 \%$ $C I=0,282-0,937)$, and education level of mother ( $p=0,6511 ;$ OR: 0,651; 95\% $C I=0,439-0,966$ ). The conclusion that the risk factor of stunting among children age 12-59 months in West Nusa Tenggara Province were weight of birth, anemia, age of mother at birth, and education level of mother.
\end{abstract}

Keywords: Stunting, Risk Factor, Toddler

\begin{abstract}
ABSTRAK
Kejadian stunting pada balita dapat memberikan dampak yang buruk bagi masa depan karena mengakibatkan petumbuhan otak anak menjadi kurang optimal. Di Provinsi Nusa Tenggara Barat pada Tahun 2017 sebanyak 37,2\% anak usia bawah 5 tahun mengalami stunting. Tujuan dari penelitian yang dilakukan adalah untuk menganalisis faktor risiko kejadian stunting pada anak usia 12-59 bulan di Provinsi Nusa Tenggara Barat.Penelitian ini merupakan hasil analisis data sekunder Indonesian Family Life Survey gelombang 5 (IFLS-5) yang diselenggarakan tahun 2014-2015. Sampel dalam penelitian ini adalah anak usia 12-59 bulan di Provinsi Nusa Tenggara Barat sebanyak 456 anak. Analisis data secara parsial dilakukan dengan Chi-Square untuk mengetahui hubungan antar variabel. Analisis secara serentak dilkukan dengan menggunakan regresi logistik untuk mengetahui risiko reatif dari kejadian stunting.Hasil penelitian menunjukkan bahwa faktor risiko kejadian stunting antara lain berat bayi lahir kurang dari 2500 gram $(\mathrm{p}=0,001 ; \mathrm{RR}=3,303$; 95\% CI = 1,6-6,816), anemia pada anak $(\mathrm{p}=0,001 ; \mathrm{RR}=2,199 ; 95 \% \mathrm{CI}=1,469-3,291)$, usia ibu saat melahirkan $<18$ tahun $(\mathrm{p}=0,001 ; \mathrm{RR}=6,867 ; 95 \% \mathrm{CI}=1,481-31,834)$, usia ibu saat melahirkan $\geq 35$ tahun $(\mathrm{p}=0,001 ; \mathrm{RR}=0,515 ; 95 \% \mathrm{CI}=0,282-0,937)$, pendidikan ibu $(\mathrm{p}=0,6511$; OR: 0,$651 ; 95 \%$ CI $=0,439-0,966)$. Dari peneitian ini dapat disimpulkan bahwa faktor risiko
\end{abstract}


kejadian stunting pada anak usia 12-59 bulan di Provinsi Nusa Tenggara Barat meliputi berat badan saat lahir, anemia pada anak, usia ibu saat melahirkan dan pendidikan ibu.

Kata kunci: Stunting, Faktor Risiko, Balita

\section{PENDAHULUAN}

Salah satu tujuan dalam Sustainable Development Goals (SDGs) yaitu menghilangkan segala bentuk malnutrisi di tahun 2030, termasuk stunting yang terjadi pada anak usia bawah 5 tahun. ${ }^{(1)}$ Stunting adalah permasalahan gizi yang dialami seorang anak dengan tinggi badan yang terlalu pendek jika berdasakan usianya. ${ }^{(2)}$ Stunting menjadi permasalahan yang perlu diperhatikan karena berkaitan dengan kurang optimalnya pertumbuhan otak sehingga berdampak pada kemampuan kognitif anak, mengganggu prestasi belajar dan menghambat anak mencapai masa depan yang lebih baik. ${ }^{(3)}$

Stunting dapat memberikan dampak buruk bagi anak baik jangka pendek maupun jangka panjang. Dampak jangka pendek dari stunting yaitu terganggunya perkembangan otak, kecerdasan, gangguan pertumbuhan fisik dan gangguan metabolisme tubuh. Dalam jangka panjang stunting dapat mengakibatkan penurunan kemampuan kognitif pada anak serta prestasi belajar. Selain itu, stunting juga dapat mengakibatkan menurunnya kekebalan tubuh anak sehingga anak mudah sakit dan risiko timbulnya penyakit di masa tua semakin tinggi. Risiko penyakit di masa tua meliputi penyakit jantung dan pembuluh darah, kegemukan, diabetes, kanker, stroke dan disabilitas. ${ }^{(4)}$
Berdasarkan data dari UNICEF, WHO dan World Bank Group diketahui bahwa di tahun 2017 sebanyak 22,2\% atau 150,8 juta anak usia bawah lima tahun di dunia mengalami stunting. Sebanyak $66 \%$ kasus terjadi pada negara dengan kategori lowermiddle income country dengan jumlah kasus terbanyak berada di Asia yaitu 83,6 juta anak. Di wilayah Asia, kasus stunting terbanyak terjadi di Asia Timur yaitu 58,7\% kasus. Asia Tenggara menempati posisi kedua untuk kasus stunting terbanyak di Asia yaitu 14,9 juta anak $^{(2)}$. Pada tahun 2017 di Indonesia terdapat $29,6 \%$ bayi bawah lima tahun (balita) mengalami stunting. ${ }^{(5)}$

Faktor yang menyebabkan stunting pada anak meliputi praktik pengasuhan yang tidak baik, terbatasnya layanan kesehatan termasuk ante natal care, post natal care dan pembelajaran dini yang berkualitas, kurangnya akses terhadap makanan bergizi, air bersih dan sanitasi. Penanganan masalah stunting dilakukan melalui intervensi spesifik dan intervensi sensitif pada 1000 hari pertama kehidupan anak sampai berusia 6 tahun. ${ }^{(4)}$

Permasalahan gizi pada balita seperti stunting tidak dapat dipandang sebelah mata, karena menyangkut masa depan generasi penerus bangsa. Oleh karena itu, banyak 
penelitian yang telah dilakukan terkait kejadian stunting pada balita. Dari hasil penelitian diketahui berat bayi lahir rendah, jenis kelamin, riwayat sakit saat usia 0-28 hari dan kemiskinan menjadi faktor risiko stunting pada anak usia 12-23 bulan. Berat bayi lahir rendah (BBLR) adalah bayi dengan berat lahir kurang dari 2500 gram. BBLR dapat disebabkan adanya kelahiran prematur (<37 minggu) atau berat bayi yang lebih kecil dari usia kehamilannya (IUGR). ${ }^{(6)}$

Ibu yang memperoleh suplementasi zat besi dan asam folat selama kehamilan dapat menurunkan risiko kejadian stunting pada anak usia di bawah 2 tahun sebesar $14 \%$ jika dibandingkan dengan ibu yang tidak pernah mengkonsumsi suplemen. Pemberian suplementasi zat besi yang baik dilakukan ketika usia kehamian kurang dari 6 bulan dengan jumlah pemberian minimal 90 butir. ${ }^{(7)}$

Ibu dengan latar belakang pendidikan rendah berisiko untuk memiliki anak stunting dibandingkan dengan ibu berpendidikan tinggi. Ibu dengan pendidikan tinggi akan memiliki pengetahuan yang lebih mengimplementasikan informasi yang diperoleh dengan baik. ${ }^{(8)}$

Kekurangan zat besi pada anak merupakan salah satu faktor risiko yang dapat menimbulkan kejadian stunting pada anak usia 2-5 tahun. Kekurangan zat besi dapat dikaitkan dengan penurunan fungsi kekebalan tubuh. Sehingga mengakibatkan tubuh akan lebih rentan terkena infeksi. ${ }^{(9)}$
Diare yang terjadi pada anak juga merupakan faktor risiko stunting. Hal ini dapat terjadi karena ketika anak sakit maka terjadi penurunan nafsu makan sehingga asupan makanan dan minuman saat anak sakit menjadi berkurang. ${ }^{(10)}$

Anak yang tidak memperoleh suplementasi vitamin A berisiko lebih besar untuk mengalami stunting. Defisiensi vitamin A dapat menyebabkan anemia dan stunting. Vitamin A memiliki peranan penting dalam proses metabolisme dalam tubuh. Selain itu suplementasi vitamin A juga dapat mencegah dampak buruk akibat diare dan campak. ${ }^{(11)}$

Kunjungan posyandu pada balita memiliki peranan penting. Frekuensi kunjungan posyandu menjadi salah satu faktor risiko kejadian stunting pada balita. Balita yang datang ke posyandu akan dilakukan penimbangan dan dipantau status gizinya. Selain itu ibu juga dapat memperoleh informasi dan penyuluhan terkait gizi dan juga kesehatan dari petugas kesehatan yang ada di posyandu. ${ }^{(12)}$

Salah satu Provinsi dengan kejadian stunting pada balita yang berada di atas ratarata nasional adalah Nusa Tenggara Barat. Kejadian stunting di Provinsi Nusa Tenggara Barat tahun 2017 sebesar 37,2\%. ${ }^{(5)}$ Oleh karena itu, peneliti tertarik untuk menganalisis faktor resiko kejadian stunting pada balita usia 12-59 bulan di Provinsi Nusa Tenggara Barat. 


\section{METODE PENELITIAN}

Penelitian ini merupakan jenis penelitian analitik dengan desain cross sectional menggunakan data sekunder hasil dari Indonesian Family Life Survey gelombang 5 (IFLS-5) pada Provinsi Nusa Tenggara Barat (NTB). IFLS-5 dilaksanakan oleh RAND Labor and Population tahun 2014-2015.

Penelitian ini dimulai dengan mengunduh data IFLS-5 dari website RAND Labor and Population, ${ }^{(13)}$ kemudian mengambil hasil survei di Provinsi NTB. Selanjutnya dilakukan pemilihan data/variabel yang akan digunakan. Data yang digunakan meliputi hasil pengukuran tinggi badan anak, usia anak, jenis kelamin, berat badan saat lahir, hasil pengukuran kadar hemoglobin anak, riwayat diare dalam satu bulan terakhir, data pemberian vitamin A dan kunjungan posyandu dalam 6 bulan terakhir. Selain itu data terkait riwayat konsumsi zat besi ibu selama kehamilan, usia ibu saat melahirkan, garam yang digunakan beryodium/tidak dan juga pendidikan ibu.

Data yang telah terkumpul dilakukan cleaning, jika data tidak lengkap maka tidak diikutsertakan dalam proses analisis data. Sampel dari penelitian ini adalah anak usia 1259 bulan di Provinsi Nusa Tenggara Barat. Dari hasil IFLS-5 diperoleh jumlah anak usia 12-59 bulan di Provinsi NTB sebanyak 600 anak. Data yang tidak lengkap/missing tidak dalam analisis sehingga sampel yang tersisa sebanyak 456 anak.
Variabel independen dalam penelitian ini yaitu berat badan anak saat lahir, status anemia anak, kejadian diare yang dialami anak dalam 4 minggu terakhir, konsumsi vitamin A dan kunjungan posyandu dalam 6 bulan terakhir, usia ibu saat melahirkan serta riwayat konsumsi zat besi selama masa kehamilan ibu.

Variabel dependen dalam penelitian ini adalah kejadian stunting pada anak. Anak dikategorikan stunting jika tinggi badan berdasarkan usia kurang dari -2SD berdasarkan standar antropometri penilaian status gizi anak yang dikeluarkan oleh Kementerian Kesehatan Republik Indonesia.(14) Untuk mengetahui faktor resiko kejadian stunting di Provinsi Nusa Tenggara Barat, data yang diperoleh dianalisis menggunakan Chi Square dan regresi logistik untuk mengetahui risiko relatif kejadian stunting.

\section{HASIL DAN PEMBAHASAN}

Hasil penelitian menunjukkan sebanyak $85,6 \%$ balita stunting memiliki berat badan lahir lebih dari 2500 gram, hal ini merupakan kondisi yang wajar karena sebagian besar responden memiliki berat lahir lebih dari 2500 gram. Hasil analisis menunjukkan ada hubungan antara berat badan lahir dengan kejadian stunting pada anak $(p=0,001)$. Seorang anak dengan berat badan lahir kurang dari 2500 gram berisiko 3,303 kali (95\% CI: 1,6-6,186) mengalami stunting jika dibandingkan dengan anak yang memiliki berat lahir 2500 gram atau lebih. 
Tabel 1. Hubungan antara Berat Badan Lahir dengan Kejadian Stunting pada Anak

\begin{tabular}{|c|c|c|c|c|c|c|}
\hline \multirow{3}{*}{ Berat Badan Lahir } & \multicolumn{4}{|c|}{ Status Gizi } & \multirow{3}{*}{ Risiko Relatif } & \multirow{3}{*}{$p$-value } \\
\hline & \multicolumn{2}{|c|}{ Stunting } & \multicolumn{2}{|c|}{ Tidak Stunting } & & \\
\hline & $\mathrm{n}$ & $\%$ & $\mathrm{n}$ & $\%$ & & \\
\hline$<2500$ gram & 29 & 14,4 & 12 & 4,7 & 3,303 (95\%CI: 1,6-6,816) & 0 \\
\hline$\geq 2500$ gram & 173 & 85,6 & 243 & 95,3 & 1 & 00 \\
\hline
\end{tabular}

Hasil yang diperoleh sejalan dengan memiliki berat lahir rendah, lebih rentan penelitian yang dilakukan di Bangladesh terkena infeksi seperti diare dan infeksi saluran dimana terdapat hubungan antara berat bayi pernafasan yang dapat menimbulkan gangguan lahir rendah $(<2500$ gram) dengan kejadian nafas saat tidur, anemia, penyakit paru kronis, stunting pada balita. Seorang anak yang kelelahan dan kehilangan nafsu makan. ${ }^{(15)}$

Tabel 2. Hubungan antara Status Anemia Anak dengan Kejadian Stunting pada Anak

\begin{tabular}{lccccccc}
\hline \multirow{3}{*}{ Status Anemia Anak } & \multicolumn{5}{c}{ Status Gizi } & \multirow{2}{*}{ Risiko Relatif } & p-value \\
\cline { 2 - 5 } & \multicolumn{2}{c}{ Stunting } & \multicolumn{2}{c}{ Tidak Stunting } & & \\
\cline { 2 - 5 } & $\mathrm{n}$ & $\%$ & $\mathrm{n}$ & $\%$ & & \multirow{2}{*}{0,001} \\
\hline Anemia & 136 & 67,3 & 127 & 50 & $2,199(95 \%$ CI: $1,469-3,291)$ & 1 & 1 \\
\hline Tidak Anemia & 66 & 32,7 & 127 & 50 & \\
\hline
\end{tabular}

Anemia adalah suatu keadaan dimana kadar hemoglobin dalam darah di bawah batas normal. Anak usia 6-59 bulan dikatakan anemia jika kadar hemoglobin dalam darah kurang dari $11 \mathrm{mg} / \mathrm{dL} .{ }^{(16)}$ Sebanyak $67,3 \%$ responden yang mengalami stunting menderita anemia. Hasil penelitian ini menunjukkan bahwa anemia merupakan salah satu faktor risiko stunting pada anak $(\mathrm{p}=0,001)$. Anemia meningkatkan resiko terjadinya stunting pada anak usia 12-59 bulan $(\mathrm{OR}=2,199 ; 95 \% \mathrm{CI}: 1,469-3,291)$.
Salah satu penyebab anemia adalah tubuh mengalami kekurangan zat besi. Jika seorang anak mengalami anemia maka hal itu dapat berdampak pada terganggunya fungsi kognitif, perilaku dan pertumbuhan. ${ }^{(17)}$

Zat besi merupakan elemen penting dalam proses pembentukan sistem kekebalan tubuh. Jika tubuh mengalami kekurangan zat besi, hal ini bisa berdampak pada respon imun tubuh. Zat besi memiliki peranan penting dalam proses pembentukan sel imun. ${ }^{(18)}$

Tabel 3. Hubungan antara Usia Ibu saat Melahirkan dengan Kejadian Stunting pada Anak

\begin{tabular}{|c|c|c|c|c|c|c|}
\hline \multirow{3}{*}{$\begin{array}{l}\text { Usia Ibu saat } \\
\text { Melahirkan }\end{array}$} & \multicolumn{4}{|c|}{ Status Gizi } & \multirow{3}{*}{ Risiko Relatif } & \multirow{3}{*}{$p$-value } \\
\hline & \multicolumn{2}{|c|}{ Stunting } & \multicolumn{2}{|c|}{ Tidak Stunting } & & \\
\hline & $\mathrm{n}$ & $\%$ & $\mathrm{n}$ & $\%$ & & \\
\hline$<18$ tahun & 13 & 6,4 & 2 & 0,8 & 2,199 (95\%CI: $1,469-3,291)$ & \\
\hline 18-34 tahun & 169 & 83,7 & 211 & 83,1 & 1 & 0,001 \\
\hline$\geq 35$ tahun & 20 & 9,9 & 41 & 16,1 & 0,515 (95\%CI: 0,282-0,937) & \\
\hline
\end{tabular}


Hasil uji statistik menunjukkan bahwa terdapat hubungan antara usia ibu saat melahirkan dengan kejadian stunting pada anak usia 12-59 bulan $(p=0,001)$. Ibu yang berusia kurang dari 18 tahun meningkatkan risiko melahirkan anak stunting 6,687 kali (95\% CI: 1,481-31,834). Sedangkan ibu dengan usia melahirkan lebih dari 35 tahun justru menurunkan risiko terjadinya stunting pada anak (OR:0,515; 95\% CI:0,282-0,987). Ibu yang melahirkan pada usia terlalu muda berisiko untuk melahirkan anak dengan berat lahir rendah, sehingga meningkatkan risiko kejadian stunting sebesar 30-40\%. ${ }^{(19)}$

Usia ibu yang terlalu muda berkaitan dengan peningkatan tinggi badan anak yang kurang maksimal pada usia 0-11 bulan, kejadian stunting ketika anak berusia 12-24 bulan dan pertumbuhan yang kurang maksimal saat usia anak lebih dari 24 bulan. Oleh karena itu dibutuhkan perhatian yang lebih bagi anak yang lahirkan oleh ibu dengan usia kurang dari 18 tahun sampai dengan anak berusia 5 tahun. ${ }^{(20)}$

Tabel 4. Hubungan antara Pendidikan Ibu dengan Kejadian Stunting pada Anak

\begin{tabular}{|c|c|c|c|c|c|c|}
\hline \multirow{3}{*}{ Pendidikan Ibu } & \multicolumn{4}{|c|}{ Status Gizi } & \multirow{3}{*}{ Risiko Relatif } & \multirow{3}{*}{$p$-value } \\
\hline & \multicolumn{2}{|c|}{ Stunting } & \multicolumn{2}{|c|}{ Tidak Stunting } & & \\
\hline & $\mathrm{n}$ & $\%$ & $\mathrm{n}$ & $\%$ & & \\
\hline Tinggi (> 9 tahun) & 81 & 40,1 & 132 & 52 & 0,651 (95\%CI: 0,439-0,966) & \multirow{2}{*}{0,015} \\
\hline Rendah ( $\leq 9$ tahun) & 121 & 59,9 & 122 & 48 & 1 & \\
\hline
\end{tabular}

Sebanyak 59,9\% balita stunting dilahirkan oleh ibu dengan pendidikan rendah. Dari hasil uji statistic diperoleh hasil bahwa terdapat hubungan antara pendidikan ibu dengan kejadian stunting pada anak $(p=0,015)$. Anak yang dilahirkan oleh ibu dengan pendidikan tinggi menurunkan risiko terjadinya stunting $(\mathrm{OR}=0,65195 \%$ CI: 0,282-0,987). Hal ini sesuai dengan penelitian sebelumnya yang menunjukkan bahwa terdapat hubungan antara pendidikan ibu dengan kejadian stunting. ${ }^{(21)}$

Seorang ibu yang berpendidikan memiliki kepedulian yang lebih tinggi terhadap status gizi dibandingkan dengan ibu yang tidak berpendidikan. Ibu memiliki perhatian lebih terhadap status gizi diri sendiri dan seluruh anggota keluarga dan mampu melakukan pengambilan keputusan sendiri terhadap permasalahan terkait status gizi keluarga. ${ }^{(21)}$

\section{SIMPULAN DAN SARAN}

\section{Simpulan}

1. Faktor risiko kejadian stunting pada anak usia 12-59 tahun di Provinsi Nusa Tenggara Barat meliputi berat bayi saat lahir, status anemia anak, usia ibu saat melahirkan dan juga pendidikan ibu.

2. Bayi yang memiliki berat lahir kurang dari 2500 gram berisiko 3,03 kali lebih besar untuk mengalami stunting. Anak yang mengalami anemia berisiko 2,199 kali lebih besar untuk mengalami stunting. 
3. Bayi yang dilahirkan oleh ibu dengan usia kurang dari 18 tahun berisiko 6,876 kali untuk mengalami stunting.

4. Ibu dengan pendidikan tinggi menurunkan risiko kejadian stunting pada anak.

5. Faktor risiko dominan dari kejadian stunting dalam penelitian ini adalah usia ibu saat melahirkan kurang dari 18 tahun.

\section{Saran}

1. Kejadian berat bayi lahir rendah dapat dicegah dengan kesiapan seorang ibu baik dari segi fisik, mental, sosial, nutrisi sebelum seorang wanita hamil.

2. Seorang wanita hendaknya menikah ketika usia lebih dari 18 tahun untuk mengurangi resiko stunting pada anak.

3. Penelitian terkait faktor lain dari kejadian stunting perlu dilakukan untuk mengetahui faktor resiko lain penyebab stunting pada anak.

\section{REFERENSI}

1. Kementerian Perencanaan Pembangunan Nasional (Bappenas); United Nations Children's Fund. Laporan Baseline SDG tentang Anak-Anak di Indonesia. Jakarta: BAPPENAS dan UNICEF; 2017.

2. United Nations Childrel's Fund; World Health Organization; World Bank Group. Level and Trends in Child Malnutrition: Key Finfing of the 2018 Edition of the Joint Child Malnutrition Estimates. Washington DC: UNICEF, WHO and World Bank Group; 2018.

3. UNICEF Pakistan. Progress Report 20132015: Stop Stunting. ; 2015.
4. Kementerian Desa, Pembangunan Daerah Tertinggal. Buku Saku dalam Penanganan Stunting; 2017.

5. Kementerian Kesehatan Republik Indonesia. Buku Saku Pemantauan Status Gizi Jakarta: Kementerian Kesehatan Republik Indonesia; 2017.

6. Aryastami NK, Shankar A, Kusumawardani $\mathrm{N}$, Besral B, Jahari AB. Low birth weight was the most dominant predictor associated with stunting among children age 12-23 months in Indonesia. BMC Nutrition. 2017 February; 3(16).

7. Nisar YB, Dibley MJ, Aguayo VM. IronFolic Acid Supplementation During Pregnancy Reduces the Risk of Stunting in Children Less Than 2 Years of Age: A Retrospective Cohort Study from Nepal. MDPI. 2016 January.

8. Bening S, Margawati A, Rosidi A. Zink Deficiency as Risk Factor among Children aged 2-5 years. Universa Medicina. 2017 April; 36(1).

9. Niga DM, Purnomo W, Hidayah SN. Relationship Between Feeding Practice with the Incidence of Stunting in Children Ages 1-2 Years in the Region of Health Center Oebobo Kupang. International Jurnal of Preventive and Public Health Sciences. 2016 Sep-Oct; 2(3).

10. Paudel R, Pahari DP, Pradhan B. Risk Factors for Stunting Among Children: A Community Based Case Control Study in Nepal. Katmandu University Medical Journal. 2012 Jul-Sep; 3(39).

11. Simanjuntak BY, Haya M, Suryani D, Ahmad CA. Early Initiation of Breastfeeding and Vitamin A Supplementation with Nutritional Status of Children Aged 6-59 Months. Kesmas: National Public Health Journal. 2018; 12(3).

12. Destiadi A, Nindya TS, Sumarmi S. Frekuensi Kunjungan Posyandu dan 
Riwayat Kenaikan Berat Badan sebagai Faktor Resiko Kejadian Stunting pada Anak Usia 3-5 Tahun. Media Gizi Indoneia. 2015 Januari-Juni; 10(1).

13. RAND Labor and Population. The ndonesian Family Life Survey. [Online].; 2014 [cited 2018 December 5. Available from: https://www.rand.org/labor/FLS/ IFLS.html.

14. Kementerian Kesehatan RI. Keputusan Menteri Kesehatan Republik IndonesiaTentang Standar Antropometri Penilaian Status Gizi Anak. ; 2011.

15. Rahman MS, Howlader T, Masud MS, Rahman LM. Association of Low-Birth Weight with Malnutrition in Children under Five Years in Bangladesh: Do Mother's Education, Socio-Economic Status, and Birth Interval Matter? Plos One. 2016 June; 11(6).

16. World Health Organization. Haemoglobin Concentratations for The Diaanosis of Anemia and Assessment of Severity. Geneva, Switzterland: World Health Organization; 2011.
17. Aridiyah FO, Rohmawati N, Ririanty M. Faktor-Fakor yang Mempengaruhi Kejadian Stunting pada Anak Balita di Wilayah Pedesaan dan Perkotaan. e-Jurnal Pustaka Kesehatan. 2015 Januari; 3(1).

18. Hasan TH, Badr MA, Karam NA, Zkaria M, Saadany HFE, Rahman DMA, et al. Impact of Iron Deficiency Anemia on the Function of the Immune System in Children. Medicine. 2016 October.

19. Sugiyarti R, Aprilia V, Hati FS. Kepatuhan Kunjungan Posyandu dan Status Gizi Balita di Posyandu Karangbendo Bangutapan, Bantul, Yogyakarta. Jurnal Ners dan Kebidanan Indonesia. 2014; 2(3).

20. Yu SH, Manson J, Crum J, Cappa C, Hotchkiss DR. Differential Effects of Young Maternal Age on Child Growth. Global Health Action. 2018 November; 9.

21. Assefa H, Belachew T, Negash L. Sociodemographic Factors Associated with Underweight and Stunting among Adolescents in Ethiopia. Pan African Medical Journal. 2015 March; 20(252). 